\title{
PEMBERDAYAAN USAHA MIKRO KECIL DAN MENENGAH DODOL KENTANG DALAM MENINGKATKAN PENDAPATAN MASYARAKAT DESA LUBUKNAGODANG KABUPATEN KERINCI PROVINSI JAMBI
}

\author{
Irma Anitia Dinita ${ }^{1}$, \\ Sampara Lukman ${ }^{2}$, Kusworo ${ }^{3}$ \\ 1) Institut Pemerintahan Dalam Negeri \\ Program Magister Terapan Studi Pemerintahan Daerah Institut Pemerintahan Dalam Negeri \\ nityadinita@gmail.com \\ ${ }^{2,3)}$ Institut Pemerintahan Dalam Negeri

\begin{abstract}
“THE EMPOWERMENT OF DODOL KENTANG (LOCAL SWEETS MADE FROM POTATO) IN JAMBI PROVINCE"
\end{abstract} \\ INCREASING THE COMMUNITY'S INCOME IN LUBUKNAGODANG VILLAGE KERINCI REGENCY,
}

\begin{abstract}
$T_{c}^{n}$ e empowerment of Dodol Kentang (local sweets made from potato) in increasing the community's income in Lubuknagodang village Kerinci regency. The empowerment of small and medium micro enterprises is held in Lubuknagodang village as the production center of potato taffy which is one of the featured products from Kerinci regency.

The purpose of this research is to find out and analyze the empowerment of Dodol Kentang as a small and medium micro enterprises in escalating the community income on Lubuknagodang village, knowing and analyzing the obstacle factors which is founded in the implementation and also to analyze and construct the follow up that is needed to handle the obstacle in empowering the potato taffy as a small and medium micro enterprises so that it would increase the community income in Lubuknagodang village. The theory that is used in this research is the empowerment theory by Pranarka and Prijono (1996) which contains: (1) Initial Phase (2) Participatory Phase (3) Emancipatory Phase. This research is also using the descriptive qualitative method and the data collecting techniques that are used is interview, observation, and documentation.

The result of this research shows that the empowerment of Dodol Kentang as a small and medium micro enterprises in increasing the community income located in Lubuknagodang village Siulak subdistrict Kerinci regency is not optimal, due to several factors such as limited budget from Kerinci regency government, training given is not equal, product marketing is modest and only covers in the production area. Aside from that, the tools for making potato taffy are still manual and modest, including the few human resources which makes it lack of innovation to the Dodol Kentang product. Therefore, in this research the writer state several suggestions in empowering the Dodol Kentang as a small and medium micro enterprises in increasing the community income on Lubuknagodang village such as: Kerinci regional government should allocate more budget, carry out product monitoring both in terms of product innovation and marketing, giving financial administration course to support the development of Dodol Kentang product. Make use of a good information media to promote the product, and make a regulation regarding Dodol Kentang as a form of protection on local products.
\end{abstract}

Keywords: micro business empowerment, small industry, home industri 


\begin{abstract}
Abstrak
$\mathrm{P}$ emberdayaan UMKM Dodol Kentang dalam meningkatkan pendapatan masyarakat Desa Lubuknagodang Kabupaten Kerinci. Pemberdayaan UMKM dilakukan di Desa Lubuknagodang sebagai sentra produksi Dodol Kentang yang merupakan salah satu produk unggulan Kabupaten Kerinci.

Penelitian ini bertujuan untuk mengetahui dan menganalisis pemberdayaan UMKM Dodol Kentang dalam meningkatkan pendapatan masyarakat di Desa Lubuknagodang, mengetahui dan menganalisis faktor penghambat yang ditemui dalam pelaksanaannya serta menganalisis dan menyusun tindak lanjut yang dilakukan dalam menangani faktor penghambat dalam pemberdayaan UMKM Dodol Kentang agar mampu meningkatkan pendapatan masyarakat di Desa Lubuknagodang. Teori yang digunakan adalah teori Pemberdayaan yang dikemukakan oleh Pranarka dan Prijono (1996), yaitu Fase Pemberdayaan: (1) Fase Inisial (2) Fase Partisipatoris, (3) Fase Emansipatoris. Penelitian ini juga menggunakan Metode kualitatif deskriptif serta teknik pengumpulan data dengan menggunakan wawancara, observasi, dan dokumentasi.

Hasil penelitian menunjukkan bahwa Pemberdayaan UMKM Dodol Kentang dalam meningkatkan pendapatan masyarakat Desa Lubuknagodang Kecamatan Siulak Kabupaten Kerinci belum optimal, karena ditemukannya beberapa faktor penghambat, yaitu Keterbatasan anggaran dari Pemerintah Kabupaten Kerinci, Pemberian Diklat yang tidak merata, Pemasaran produk yang masih sederhana dan terbatas di sekitar tempat produksi. Selain itu, alat-alat pembuat Dodol Kentang yang masih manual dan sederhana, serta kualitas SDM yang masih rendah yang menyebabkan rendahnya inovasi terhadap produk UMKM Dodol Kentang. Oleh karena itu, dalam penelitian ini penulis menyampaikan beberapa saran dalam Pemberdayaan UMKM Dodol Kentang dalam meningkatkan Pendapatan Masyarakat di Desa Lubuknagodang yaitu Pemerintah Daerah Kabupaten Kerinci hendaknya mengalokasikan anggaran yang lebih banyak, Pelaksanaan monitoring atas pengembangan Dodol Kentang baik pada aspek inovasi produk maupun pemasarannya, memberikan pelatihan administrasi keuangan untuk menunjang perkembangan UMKM Dodol Kentang.Memanfaatkan media informasi yang baik untuk mempromosikan produk Dodol Kentang, serta Membuat Peraturan mengenai Dodol Kentang sebagai wujud perlindungan atas produk lokal.
\end{abstract}

Kata kunci: pemberdayaan UMKM, usaha mikro, industri kecil

\section{PENDAHULUAN}

$\mathrm{P}$ ada masa pandemi covid 19 seperti saat ini pemerintah mengambil langkah serius untuk meningkatkan usaha mikro kecil menengah (UMKM). Direktur Jenderal Pengelolaan Pembiayaan Risiko Kementerian Keuangan, Lucky Alfirman, menyebutkan "Peran UMKM dirasa sangat penting terhadap perekonomian indonesia". UMKM berpotensi untuk menguasai pasar dalam negeri saat pandemi, terutama saat kebutuhan impor tidak berjalan seperti ketika situasi normal.

Pemerintah berusaha memberdayakan UMKM agar menjadi usaha yang tangguh dan mandiri. Bentuk pemberdayaan itu dilakukan dengan memastikan bahwa UMKM mendapat pemihakan, kepastian, kesempatan, perlindungan, dan dukungan berusaha seluas mungkin. Selain pemberdayaan, pemerintah juga memberi dukungan dalam bentuk pengembangan, pembiayaan, penjaminan, dan kemitraan.

Usaha mikro kecil dan menengah di Kabupaten Kerinci kondisinya belum maksimal. Hal ini terlihat dari masih kecilnya kontribusi sektor Lapangan Usaha Pengolaan terhadap Pendapatan Domestik Regional Bruto (PDRB) Kabupaten Kerinci. Sehingga untuk peningkatan kontribusi diperlukan sumber daya manusia pelaku usaha industri kecil di Kabupaten Kerinci yang memiliki 
kemampuan untuk menerima inovasi teknologi dan penambahan wawasan serta pengetahuan.

Dalam melakukan pemberdayaan UMKM Dodol Kentang, Pemerintah Kabupaten Kerinci telah melakukan berbagai usaha, yaitu berupa pemberian dana dan bantuan peralatan mesin adukan dodol, kuali dan oven, selain itu juga dilakukan pembinaan dengan adanya pelatihan dan penyuluhan bagi pelaku usaha pembuat Dodol Kentang serta pameran untuk memperkenalkan dan memasarkan Dodol Kentang sebagai makanan khas Kabupaten Kerinci.

Kemampuan industri kecil dan menengah di Kabupaten Kerinci dalam memberikan lapangan pekerjaan kepada masyarakat golongan menengah ke bawah berdampak positif,UMKM Dodol Kentang Kabupaten Kerinci mampu menyerap tenaga kerja yang cukup besar, bila dibandingkan dengan UMKM berbasis bahan baku lokal yang lainnya.

Pembuatan Dodol Kentang masih sederhana, dengan menggunakan peralatan yang manual sehingga membutuhkan waktu yang cukup lama, terutama dalam proses pengeringan membutuhkan waktu dua hari jika cuaca cerah bahkan sampai satu minggu jika cuaca kurang baik, sedangkan jika menggunakan oven, waktu yang digunakan untuk proses pengeringan jauh lebih singkat, yakni 3-4 jam saja. Jadi ini merupakan permasalahan yang sangat membutuhkan perhatian dari pemerintah. Karena harga oven yang mahal pelaku UMKM Dodol Kentang tidak mampu untuk melakukan pengadaan secara mandiri

Didalam pembinaan dan pengembangan oleh berbagai instansi berbagai program dijalankan melalui pendekatan proyek, sehingga program tersebut berjalan sebatas masa proyeknya. Begitu masa proyeknya selesai, maka program itu dilepaskan begitu saja. Perhatian para pelaksana atau instansi yang melaksanakan program tersebut hanya selama pemberdayaan usaha kecil. Dalam hal ini pemerintah sendiri tidak mempersiapkan tindakan yang harus dilakukan pasca proyek. Berbagai program dilakukan berbagai instansi nampak tidak terkoordinasi dengan baik. Masing-masing instansi melaksanakan programnya dengan mekanisme tersendiri dan di lapangan terjadi tumpang tindih.

Di samping itu, terlalu banyak persoalan yang menjadi beban para pembuat Dodol Kentang, mulai dari lamanya proses pencairan modal atau dana simpan pinjam dari pemerintah yang dari proses pengajuan sampai cairnya pinjaman modal bisa menghabiskan waktu satu sampai dua tahun, alat pembuat dodol yang masih tradisional, pemasaran, daya tahan dodol yang tidak lama, yaitu hanya bertahan satu bulan, sampai kepada konflik antar pembuat Dodol Kentang itu sendiri yang berdampak pada persaingan harga dan kualitas. Selain itu, pendidikan yang relatif rendah, rendahnya inovasi dalam pemberdayaan produk terutama pada kemasan yang masih menggunakan plastik mika biasa yang terlihat kurang menarik, dan lemahnya penguasaan manajemen.

Dalam penelitian ini, fokusnya ditekankan padapemberdayaan UMKMDodol Kentang dalam meningkatkan pendapatan masyarakat di Desa Lubuknagodang. Pemberdayaan Dodol Kentang ini ini selain bertujuan kepada peningkatan pendapatan masyarakat, Dodol Kentang juga merupakan produk unggulan Provinsi Jambi, mengingat Dodol Kentang ini di produksi dengan memanfaatkan bahan baku lokal, yaitu Kentang yang merupakan produk unggulan hasil pertanian di Kabupaten Kerinci. Pemberdayaan Dodol Kentang dimaksudkan untuk menjadi oleh-oleh khas kabupaten kerinci dalam meningkatkan pariwisata, menjaga stabilitas ekonomi dan secara lebih jauh mampu meningkatkan pendapatan masyarakat di Desa Lubuknagodang, mengingat dalam beberapa tahun terakhir Dodol Kentang mengalami penurunan jumlah produksi, hal ini disebabkan karena 
berbagai faktor baik internal maupun eksternal, sehingga dipandang sangat perlu sebuah strategi pemberdayaan yang mampu mengangkat citra Dodol Kentang baik di mata nasional maupun internasional. Desa Lubuknagodang Kecamatan Siulak Kabupaten Kerinci merupakan satu-satunya desa yang berbasis UMKM Dodol Kentang, sehingga tepat bila menjadi lokasi penelitian ini.

Kerangka pemikiran ini mengacu pada konsep Pranarka dan Priyono (1996: 44-46) tentang tiga fase yang harus dilakukan dalam memberdayakan masyarakat atau kelompok, yang terbagi dalam tiga fase, yaitu fase inisial, partisipatoris, dan emansipatoris.

Pada fase inisial, semua proses pemberdayaan berasal dari pemerintah, oleh pemerintah dan diperuntukkan bagi masyarakat. Pada fase ini masyarakat bersifat pasif, melaksanakan apa yang direncanakan pemerintah dan tetap tergantung kepada pemerintah. Pada fase partisipatoris, proses pemberdayaan berasal dari pemerintah bersama masyarakat, oleh pemerintah bersama masyarakat, dan diperuntukkan bagi masyarakat. Pada fase ini masyarakat sudah dilibatkan secara aktif dalam kegiatan pembangunan untuk menuju kemandirian. Kemudian ketika fase emansipatoris, proses pemberdayaan berasal dari masyarakat, oleh masyarakat dan untuk masyarakat dengan dukungan oleh pemerintah. Pada fase ini masyarakat sudah menemukan kekuatan dirinya, sehingga dapat melakukan kekuatan dirinya, sehingga dapat melakukan pembaharuan dalam mengaktualisasikan diri.

Menurut Pranaka dan Moeljarto dalam Pranarka dan Prijono (1996: 44) pemberdayaan (empowerment) pada dasarnya mengacu pada usaha menumbuhkan keinginan kepada seseorang dan pemberian peluang serta kesempatan bagi bawahan untuk mengaktualisasikan diri, meningkatkan potensi dan kemampuan yang dimiliki, serta memberikan pengalaman psikologis yang membuat seseorang merasa berdaya.

Pencapaian hasil pemberdayaan pada UMKM Dodol Kentang tidak hanya diprioritaskan sampai pada meningkatnya

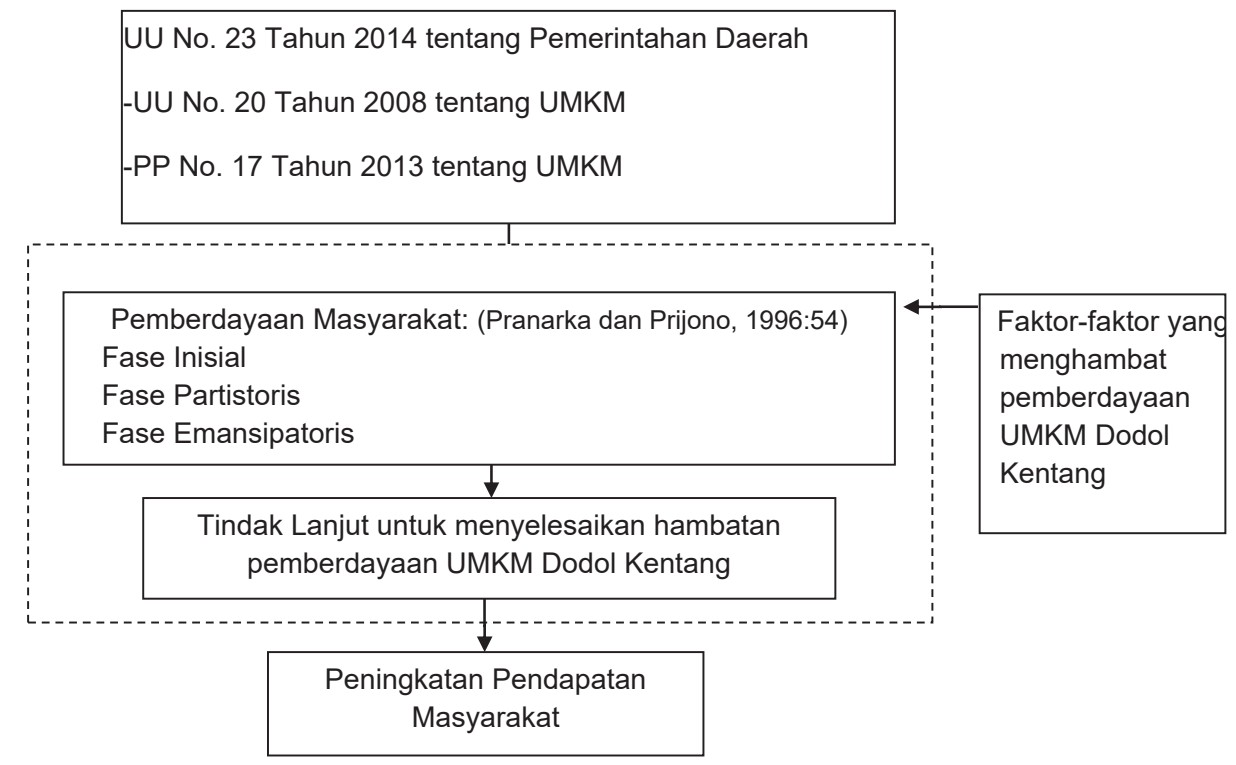

Gambar 1

Kerangka Pemikiran

Sumber: Diolah Penulis Tahun 2021 
hasil produksi saja, akan tetapi implikasinya harus dapat dirasakan dari subjek usaha kecil itu, dalam hal ini masyarakat dan pelaku industri secara khusus. Apakah dampak meningkatnya suatu usaha sejalan dengan meningkatnya taraf hidup maupun pendapatan pelakunya, Itu sangat diharapkan dalam rangka berputarnya kembali siklus usaha, yang dimulai dari proses mendapatkan faktor produksi hingga tercapainya kembali hasil produksi yang memuaskan. Dengan pemberdayaan ini diharapkan mampu meningkatkan pendapatan masyarakat di Desa Lubuknagodang sebagai masyarakat pengusaha Dodol Kentang di Kabupaten Kerinci. Dinas Koperasi dan Tenaga Kerja Kabupaten Kerinci selaku pelaksana teknis yang menangani masalah pemberdayaan UMKM Dodol Kentang ini dituntut untuk berperan lebih dalam menentukan keberhasilan program pemberdayaan UMKM Dodol Kentang itu sendiri.

\section{METODE PENELITIAN}

Pendekatan yang digunakan dalam penelitian ini adalah metode kualitatif. Moleong (2014: 6) menyatakan bahwa "penelitian kualitatif adalah penelitian yang bermaksud untuk memahami fenomena tentang apa yang dialami oleh subjek penelitian". Penelitian ini bertujuan untuk mengetahui dan menganalisis Pemberdayaan UMKM Dodol Kentang dalam Meningkatkan Pendapatan Masyarakat Desa Lubuknagodang Kecamatan Siulak Kabupaten Kerinci Provinsi Jambi. Sumber data dalam penelitian ini pertama, yaitu orang yang bisa memberikan data dan informasi secara maksimal untuk penelitian ini, yang disebut informan. Kedua, yaitu dokumen yang berkaitan dengan penelitian ini, baik berupa buku, peraturan-peraturan, bahan bacaan lainnya yang dapat digunakan dalam penelitian ini. Dan yang ketiga, yaitu tempat, dalam penelitian ini tempat yang dimaksud dapat berupa lokasi usaha mikro kecil menengah Dodol Kentang di desa Lubuknagodang, Dinas Koperasi dan Tenaga
Kerja serta tempat lain yang menyajikan informasi mengenai penelitian ini.

Informan dalam penelitian ini diperoleh dengan teknik key person dan teknik sampling yang digunakan adalah purposive sampling, di mana penulis memandang kalau pengusaha/pembuat Dodol Kentang dapat memberikan data dan informasi kepada penulis secara maksimal. Menurut Sugiyono (2017: 218) "purposive sampling adalah teknik pengambilan sampel sumber data dengan pertimbangan tertentu". Sedangkan untuk memperoleh informasi yang tepat diperlukan informan yang mengetahui materi. Pengambilan sampel melalui key informan, yaitu orang-orang yang memberikan informasi karena mengetahui materi, dan dengan demikian yang bersangkutan dapat memberikan keterangan yang representatif.

Dalam penelitian ini penelitian ini penulis menggunakan metode wawancara, maka instrumennya adalah pedoman wawancara dengan menggunakan pedoman wawancara sebagai instrumennya maka penulis melakukan wawancara serta pencatatan terhadap data yang diperlukan terkait pemberdayaan UMKM Dodol Kentang di Desa Lubuknagodang. Untuk analisis data dalam penelitian ini dilakukan dengan cara data Reduction (Data Reduksi), Data Display (Penyajian Data) dalam penelitian kualitatif penyajian data dilakukan dalam bentuk uraian singkat, bagan, hubungan antar kategori, flowchart dan sejenisnya. Selanjutnya Conclusion Drawing/Verification, Langkah ketiga dalam analisis data kualitatif menurut Miles and Huberman adalah penarikan simpulan dan verifikasi.

\section{HASIL PENELITIAN DAN PEMBAHASAN \\ Pemberdayaan UMKM Dodol Kentang di Desa Lubuknagodang}

\section{- Fase Inisial}

Berdasarkan fokus penelitian dalam fase ini terbagi dalam beberapa indikator sebagai 
tolok ukur dalam memberdayakan UMKM Dodol Kentang. Adapun indikator yang dimaksud adalah pelatihan, penyuluhan, dan kebijakan yang dirumuskan terkait dengan pengembangan UMKM.

\section{Pelatihan}

Berdasarkan hasil observasi di lapangan diperoleh data bahwa telah dilakukan aktivitas pendidikan dan pelatihan bagi para pengusaha dan pembuat Dodol Kentang, baik yang bersifat teknis maupun nonteknis. Kemudian diperkuat dengan hasil studi dokumentasi yang telah dilakukan oleh penulis didapatkan informasi bahwa pemerintah telah melaksanakan pendidikan dan pelatihan bagi pengusaha dan pembuat Dodol Kentang seperti di antaranya: pelatihan teknis, pelatihan Peningkatan Mutu, Pelatihan Kemasan dan Labeling serta Magang ke Garut Jawa Barat

2. Penyuluhan

Penyuluhan sebagai proses komunikasi pembangunan, penyuluhan tidak sekadar upaya untuk menyampaikan pesan-pesan pembangunan, tetapi yang lebih penting dari itu adalah untuk menumbuhkembangkan partisipasi masyarakat dalam pembangunan (mardikanto: 2013). Dalam pemberdayaan UMKM Dodol Kentang penyuluhan dianggap penting sebagai salah satu cara untuk menggerakkan masyarakat untuk melakukan perubahan.

Hasil observasi di lapangan diperoleh data bahwa penyuluhan dulu pernah dilakukan pada saat awal terbentuknya UMKM Dodol Kentang. Namun sejauh ini, penyuluhan sudah tidak lagi dilakukan oleh Dinas Koperasi dan Tenaga Kerja.

3. Kebijakan

Selain pelatihan dan penyuluhan, kebijakan pemerintah sangat berpengaruh dalam memberdayakan
UMKM Dodol Kentang. Kebijakan yang dikeluarkan oleh Pemerintah Kabupaten Kerinci dijadikan sebagai arah dan pedoman dalam pengembangan UMKM Dodol Kentang. Salah satu kebijakan yang dikeluarkan oleh pemerintah daerah Kabupaten Kerinci adalah keputusan bupati Kerinci No. 500/ Kep.186/2016 tentang Penetapan Produk Unggulan Daerah Kabupaten Kerinci menyebutkan Dodol Kentang menjadi salah satu produk unggulan dari Kabupaten Kerinci.

\section{- Fase Partisipatoris}

Fase partisipatoris bisa dilaksanakan ketika fase inisial telah menampakkan hasil yang sesuai dengan harapan. Adapun yang menjadi hasil penelitian berdasarkan indikator dalam fase ini adalah sebagai berikut.

1. Keterlibatan masyarakat dalam setiap program

Fase partisipatoris merupakan proses pemberdayaan yang berasal dari pemerintah bersama masyarakat, oleh pemerintah dan masyarakat, dan diperuntukkan bagi masyarakat. Pada tahap partisipatoris, proses pemberdayaan pada dasarnya dari pemerintah bersama rakyat dan diperuntukkan bagi rakyat. Pada tahap ini peran pemerintah semakin dikurangi dengan melibatkan masyarakat secara aktif guna menuju kemandirian. Ini bisa dilihat pada tingkat partisipasi masyarakat sebagai pelaku usaha yang cukup berminat pada setiap pelatihan yang dilaksanakan oleh Dinas Koperasi dan Tenaga Kerja Kabupaten Kerinci.

2. Antusias masyarakat dalam program pemberdayaan

Antusias masyarakat dalam program pemberdayaan UMKM yang dilaksanakan pada Kabupaten Kerinci juga cukup besar. Dari hasil wawancara 
Kepala Bidang Koperasi dan UMKM menyebutkan bahwa:

"Antusiasme masyarakat dalam pemberdayaan UMKM Dodol Kentang ini dirasakan sangat tinggi. Bahkan yang tidak ikut pelatihanpun tertarik mendengar pengalaman yg lainnya. Banyak masyarakat yang tertarik dan mulai membuka unit usaha Dodol Kentang secara mandiri, kecil-kecilan sebagai industri rumah tangga untuk mendapatkan penghasilan tambahan dengan memproduksi Dodol Kentang".

Berdasarkan hasil observasi di lokasi penelitian diperoleh data bahwa telah dilakukan kegiatan penumbuhan kemandirian dan pemecahan masalah yang dialami oleh para pengrajin dan pengusaha, yang diwujudkan dengan adanya koperasi Kayo yang menaungi seluruh pelaku usaha Dodol Kentang, koperasi ini juga mulai dirasakan manfaatnya bagi para anggota, karena pada masa sulit pelaku usaha tetap dapat mengembangkan usahanya dengan pinjaman dari koperasi.

\section{- Fase Emansipatoris}

Telah kita pahami bahwa pada tahap ini masyarakat telah berdaya dan mempunyai kemampuan dalam mengembangkan usahausahanya. Oleh sebab itu pemberdayaan yang dilakukan oleh Dinas Koperasi dan Tenaga Kerja Kabupaten Kerinci harus disesuaikan dengan kondisi mereka. Untuk memberdayakan usaha-usaha ini perlu adanya dukungan, perlindungan dan pengembangan sepenuhnya dan seluasluasnya dari dinas terkait. Kondisi dari usaha-usaha di bidang perdagangan saat ini belum bisa menggunakan fase ini, karena kebanyakan dari usaha yang ada masih belum menemukan kemampuannya untuk untuk memberdayakan usahanya sendiri dilihat dari banyaknya usaha yang sudah tidak aktif. Oleh karena itu, Dinas Koperasi dan Tenaga Kerja harus selalu memberi dukungan kepada usaha-usaha yang menggunakan fase ini. Adapun hasil penelitian dari indikator dalam fase ini adalah sebagai berikut.

1. Aset

Aset merupakan sesuatu yang dimiliki masyarakat (pelaku usaha) guna mengembangkan usaha mereka. Aset UMKM Dodol Kentang dapat dilihat berdasarkan kriteria UMKM sesuai dengan ketentuan Undang-Undang No. 20 Tahun 2008 tentang Usaha Mikro Kecil Menengah. Dalam hal ini aset usaha dikalkulasi secara keseluruhan dari datadata yang diperoleh oleh Dinas Kopnaker Kabupaten Kerinci, yakni aset usaha kecil mencapai 50 juta dan untuk usaha mikro mencapai 300 juta. Sedangkan aset usaha menengah mencapai 1 miliar. Ini membuktikan bahwa UMKM cukup menjanjikan pada sisi asetnya.

2. Volume Usaha

Volume usaha merupakan bina usaha yang diperoleh dari pengadaan atau pengorbanan untuk menjalankan usaha masyarakat sebagai pelaku usaha. Adapun volume usaha dalam hal ini dihitung secara menyeluruh dari UMKM Dodol Kentang..

3. Sisa Hasil Usaha

Sisa hasil usaha merupakan salah satu bukti bahwa usaha tersebut berkembang karena bisa digunakan untuk lebih mengembangkan usaha tersebut. Sisa hasil usaha diperoleh dari volume usaha yang bersumber dari aset usaha. Secara umum sisa hasil usaha juga dihitung secara menyeluruh untuk semua unit usaha UMKM Dodol Kentang yang terdaftar pada Dinas Kopenaker Kabupaten Kerinci. Faktor-Faktor Penghambat Pember-
dayaan UMKM Dodol Kentang

Faktor-faktor penghambat pemberdayaan UMKM Dodol Kentang di 
Desa Lubuknagodang Kecamatan Siulak Kabupaten Kerinci dalam meningkatkan pendapatan masyarakat Desa Lubuknagodang Kecamatan Siulak Kabupaten Kerinci adalah sebagai berikut.

a. Proses pembuatan yang lama dan masih menggunakan peralatan yang manual, karena sarana dan prasarana yang dimiliki para pelaku usaha Dodol Kentang khususnya di Desa Lubuknagodang masih sangat terbatas dan sederhana.

b. Bantuan pemerintah. Bantuan pemerintah terutama yang berupa mesin penggiling Dodol Kentang belum merata, dari 60 unit usaha Dodol Kentang hanya 11 unit usaha yang mendapatkan, sedangkan unit usaha yang lainnya masih memanfaatkan tenaga manusia secara manual.

c. Pemasaran produk Dodol Kentang yang masih sederhana di mana konsumen harus datang langsung pada tempat penjualan produk Dodol Kentang. Tempat penjualan produk Dodol Kentang tersebut di Kabupaten Kerinci masih terbatas jumlahnya. Meskipun sudah ada beberapa unit usaha Dodol Kentang yang mulai menyalurkan Dodol Kentang ke beberapa toko di pusat Kota Sungaipenuh dan beberapa supermarket di ibu kota Provinsi Jambi.

d. Keterbatasan Anggaran. Alokasi anggaran yang diberikan pemerintah memang terbatas, sehingga belum bisa maksimal.

e. Tenaga Kerja masih kurang dan Kualitas Sumber Daya Manusia, yaitu para pembuat Dodol Kentang masih rendah di mana inovasi dan kreativitas yang dimiliki para pembuat Dodol Kentang masih lemah dan terbatas. Belum lagi jumlah tenaga kerja pembuat Dodol Kentang yang terbatas dan masih membutuhkan tenaga kerja untuk dapat memenuhi kebutuhan dan permintaan. f. Konflik Antar-Pengusaha. Belum adanya kesepakatan dan kesepahaman antar pelaku usaha Dodol Kentang karena terjadinya persaingan AntarPengusaha, dan berdasarkan hasil studi dokumentasi diperoleh informasi bahwa para pengusaha menjalankan usahanya hanya sebatas mencari keuntungan dan untuk bertahan hidup, sehingga belum adanya kesepakatan harga di antara para pengusaha yang memicu perbedaan dan permasalahan.

\section{Tindak Lanjut Pemerintah Kabupaten Kerinci}

Tindak lanjut Pemerintah Kabupaten Kerinci yang telah dilakukan dalam menghadapi faktor-faktor penghambat pemberdayaan UMKM Dodol Kentang dalam meningkatkan pendapatan masyarakat Desa Lubuknagodang Kecamatan Siulak Kabupaten Kerinci adalah sebagai berikut.

a. Kemitraan dengan pihak luar atau swasta, yaitu dengan mengajak para investor untuk bersedia menanamkan modalnya di Kabupaten Kerinci terutama untuk menunjang produksi Dodol Kentang. Selain itu bekerja sama dengan daerah lain guna menyediakan dan mengirim pasokan produk Dodol Kentang Kabupaten Kerinci.

b. Tenaga Kerja, untuk memenuhi kebutuhan akan tenaga kerja dipenuhi oleh para pengusaha dengan cara merekruit dari tenaga kerja non terampil yang kemudian dipekerjakan. Sedangkan dalam hal meningkatkan kualitas SDM tenaga kerja, Pemerintah Kabupaten kerinci menyelenggarakan pendidikan dan pelatihan kepada para Pelaku UMKM Dodol Kentang guna peningkatan kualitas baik pembuat maupun produk Dodol Kentang.

c. Konflik Antar-Pengusaha, solusi yang dilakukan adalah dengan menguatkan kembali fungsi Koperasi Wanita 
Kayo yang merupakan perkumpulan pengusaha Dodol Kentang Desa Lubuknagodang.

\section{SIMPULAN}

Pertama, pemberdayaan UMKM Dodol Kentang dalam meningkatkan pendapatan masyarakat Desa Lubuknagodang Kecamatan Siulak Kabupaten Kerinci belum optimal. Hal ini tampak pada aspek:

a. Pemberdayaan UMKM Dodol Kentang

1) Fase Inisial, bahwa Pemerintah Kabupaten Kerinci telah mengupayakan situasi perekonomian yang stabil dan mendorong pengembangan potensi yang dimiliki UMKM Dodol Kentang pada aspek varian maupun pemasaran meskipun belum sepenuhnya para pengusaha mampu melaksanakannya.

2) Fase Partisipatoris, bahwa Dinas Koperasi dan Tenaga Kerja Kabupaten Kerinci telah melaksanakan program pendidikan dan pelatihan kepada para Pembuat Dodol Kentang demi peningkatan kualitas SDM para pembuat Dodol Kentang sehingga mampu menemukan solusi terhadap permasalahan yang mereka hadapi secara lebih mandiri meskipun belum seluruh pelaku usaha Dodol Kentang menerima pendidikan dan pelatihan tersebut.

3) Fase Emansipatoris, bahwa Pemerintah Kabupaten Kerinci belum menetapkan produk hukum daerah mengenai Dodol Kentang, sebagai wujud perlindungan atas produk Lokal serta melakukan pengawasan kepada para pelaku usaha Dodol Kentang sehingga terhindar dari monopoli dan mampu mengembangkan usahanya.
Sehingga belum dirasakan hasil yang maksimal dalam fase ini.

b. Pendapatan pelaku usaha UMKM Dodol Kentang Desa Lubuknagodang Kecamatan Siulak Kabupaten Kerinci

Bahwa Pemberdayaan UMKM Dodol Kentang masih terdapat kekurangan terutama dalam hal administrasi keuangan yang belum mereka miliki.

Kedua, faktor-faktor penghambat pemberdayaan UMKM Dodol Kentang dalam meningkatkan pendapatan masyarakat Desa Lubuknagodang Kecamatan Siulak Kabupaten Kerinci yaitu, yakni proses pembuatan yang lama dan masih menggunakan peralatan yang manual. Bantuan pemerintah terutama yang berupa mesin penggiling Dodol Kentang belum merata, pemasaran produk masih terbatas. Meskipun sudah ada beberapa unit usaha Dodol Kentang yang mulai menyalurkan Dodol Kentang ke beberapa toko di pusat Kota Sungaipenuh dan beberapa supermarket di ibu kota Provinsi Jambi. Tenaga kerja masih kurang dan kualitas sumber daya manusia masih rendah di mana inovasi dan kreativitas masih rendah. Demikian pula, adanya konflik antar-pengusaha, sehingga belum adanya kesepakatan harga di antara para pengusaha yang memicu perbedaan dan permasalahan.

Ketiga, tindak lanjut Pemerintah Kabupaten Kerinci yang telah dilakukan dalam menghadapi faktor-faktor penghambat pemberdayaan UMKM Dodol Kentang dalam meningkatkan pendapatan masyarakat Desa Lubuknagodang Kecamatan Siulak Kabupaten Kerinci, yaitu melakukan kemitraan dengan pihak luar atau swasta, untuk memenuhi kebutuhan akan tenaga kerja dipenuhi oleh para pengusaha dengan cara merekruit dari tenaga kerja nonterampil yang kemudian dipekerjakan. Menyelenggarakan pendidikan dan pelatihan kepada para Pelaku UMKM Dodol Kentang guna peningkatan kualitas SDM, dan menguatkan kembali fungsi 
Koperasi Wanita Kayo yang merupakan perkumpulan pengusaha Dodol Kentang Desa Lubuknagodang.

\section{SARAN}

Berdasarkan simpulan di atas, penulis sarankan sebagai berikut. Pertama, dalam pemberdayaan UMKM Dodol Kentang, hendaknya Dinas Koperasi dan Tenaga Kerja diharapkan untuk dapatmelakukan monitoring secara berkelanjutan agar pengembangan Dodol Kentang baik pada aspek inovasi produk maupun pemasarannya menjadi lebih optimal. Kedua, Dinas Koperasi dan Tenaga Kerja Kabupaten Kerinci hendaknya merencanakan dan mengatur secara proporsional siapa saja pelaku usaha Dodol Kentang yang menerima pendidikan dan pelatihan tersebut sehingga pelaku UMKM yang telah menerima pendidikan dan pelatihan tersebut mampu untuk membagi ilmu yang diterimanya kepada unit usaha lainnya karena dihadapkan dengan keterbatasan tenaga pendidik serta anggaran yang ada.

Ketiga, dalam rangka mempromosikan produk Dodol Kentang, Pemerintah Kabupaten Kerinci diharapkan membuat peraturan mengenai Dodol Kentang, sebagai wujud promosi perlindungan atas produk Lokal, seperti mewajibkan menggunakan Dodol Kentang sebagai sajian "welcome drink" kepada tamu yang datang pada setiap penginapan, Hotel ataupun acara resmi yang dilaksanakan Kabupaten Kerinci. Selain itu Pemerintah Kabupaten Kerinci diharapkan dapat Menyediakan website khusus yang terpadu bagi para pelaku UMKM Dodol Kentang sehingga dapat mempromosikan hasil produksinya hingga menjualnya secara online.

\section{DAFTAR RUJUKAN}

Agustino, Leo. 2008. Dasar-Dasar Kebijakan Publik, Bandung: Alfabeta

Anwas, Oos M, 2014, Pemberdayaan Masyarakat di Era Global, Alfabeta: Bandung
Arikunto, Suharsimi, 2013, Prosedur Penelitian: Suatu Pendekatan Praktik, Rineka Cipta, Jakarta

Armelia, Gita Rosalita dan Anita Damayantie, Jurnal Sociologie Vol 1, Peran PTPN VII dalam Pemberdayaan Home Industri Keripik Pisang.

A.S, Moenir., 1992. Manajemen Pelayanan Umum di Indonesia, Bumi Aksara: Jakarta.

Bryson, John M, 2008, Perencanan Strategis Bagi Organisasi Sosial, Pustaka Belajar, Yogyakarta.

Bungin, Burhan, 2010, Penelitian kualitatif, Kencana Prenada Media Group, Jakarta.

Denzin, N.K., \& Lincoln Y.S. 2009. Hand Book of Qualitative Research. Yogyakarta: Pustaka Pelajar

Gunawan, Iman. 2013. Metode Penelitian Kualitatif: Teori dan Praktik. Jakarta: Bumi Aksara.

Effendi, Khasan, 2010. Sosiologi Pemerintahan, Bandung: CV.Indra Prahasta.

Herdiansyah, Haris. 2013. Wawancara, Observasi, dan Focus Groups. Jakarta, Raja Grafindo Persada.

Hikmat, Harry, 2013, Strategi Pemberdayaan Masyarakat, Humaniora. Bandung.

Hunger J. David dan Thomas L. Wheelen, 2003, Manajemen Strategis, Andi, Yogyakarta.

Mardikanto, T dan Poerwoko Soebiato, 2017, Pemberdayaan MasyarakatDalam Perspektif Kebijakan Publik, Alfabeta, Bandung.

Moleong, Lexy J, 2014, Metodologi Penelitian kualitatif, PT Remaja Rosdakarya, Bandung.

Najiati,Sri. Agus Asmana, I Nyoman N. Suryadiputra, 2005, Pemberdayaan Masyarakat di Lahan Gambut, Bogor: Wetlands International - 1P

Nasution, 2014, Metode Research, Bumi Aksara, Jakarta.

Nazir, Mohammad, 2014. Metode Penelitian, Bogor, Ghalia Indonesia.

Ndraha, Taliziduhu, 2008, Kybernologi Kepamongan, Credentia Centre, Sirao Banten. 
Perangin angin, Loina, 2001. Hubungan Masyarakat: Membina Hubungan Baik Dengan Publik. CV. Lalolo, Bandung

Prijono, Onny S dan Pranarka, A.M.W, 1996. Pemberdayaan: Konsep, Kebijakan dan Implementasi, CSIS, Jakarta.

Rangkuti, Freddy, 2008, Analisis Swot Teknik Membedah Kasus Bisnis, P.T. Gramedia Pustaka Utama, Jakarta.

, 2015, Teknik Membedah Kasus Bisnis Analisis SWOT: Cara Perhitungan Bobot, Rating, dan OCAI, P.T. Gramedia Pustaka Utama, Jakarta.

Rasyid, M. Ryaas, 1997, Kajian Awal Birokrasi, Yarsif Watampone, Jakarta

Roesmidi dan Risyanti, 2006, Pemberdayaan Masyarakat, Alqaprint, Sumedang.

, 2008, Pemberdayaan Masyarakat, Alqaprint, Sumedang.

Salusu, J, 2008, Pengambilan Keputusan Strategis Untuk Organisasi Publik dan Organisasi Nonprofit, PT Grasindo, Jakarta.

Sedarmayanti, 2014, Manajemen Sumber Daya Manusia,Reformasi Birokrasi dan Manajemen Pegawai Negeri Sipil, P.T.Refika Aditama, Bandung.

Sitompul, Rudi, 1984, Keuangan Negara, Erlangga, Bandung.
Subanar, Harimurti, 2001, Manajemen Usaha Kecil, Kanisius, Yogyakarta.

Sugiyono, 2017, Metode Penelitian Kuantitatif, Kualitatif dan R\&B, edd. CV.Alfabeta, Bandung.

Suharto, Edi, 2014, Membangun Masyarakat Memberdayakan Rakyat, Refika Aditama, Bandung.

Sumaryadi, I Nyoman, 2005, Perencanaan Pembangunan Daerah Otonom dan Pemberdayaan Masyarakat, Citra Utama, Jakarta.

Sutopo, HB, 2006, Metode Penelitian Kualitatif, Surakarta, UNS Press.

Tambunan, Tulus T.H, 2002, Usaha Kecil Mikro dan Menengah di Indonesia: Beberapa Isu Penting, Jakarta: PT Salemba Empat

Tjokroamidjojo, Bintoro dan A. R. Mustopadijaya, 1998, Teori dan Strategi Pembangunan Nasional, C.V. Haji Masagung, Jakarta.

Wasistiono, Sadu, 2003, Kapita Selekta Manajemen Pemerintahan Daerah, Fokus media, Bandung.

, 2003, Prospek Pengembangan Desa, Fokus media, Bandung.

Yustika, Ahmad Erani, 2003, Negara Vs Kaum Miskin, Pustaka Belajar, Yogyakarta. 
Virioner - Vol. $13 \backslash$ No. $2 \backslash$ Agustus 2021 